International Journal of Environment, Agriculture and Biotechnology
Vol-6, Issue-6; Nov-Dec, 2021
J Journal Home Page Available: https://ijeab.com/
Journal DOI: $10.22161 /$ ijeab

Peer Reviewed

\title{
An Assessment of Singapore Airlines Environmentally Sustainable Energy Management
}

\author{
Glenn Baxter
}

School of Tourism and Hospitality Management, Suan Dusit University, Thailand.

Email: g_glennbax@dusit.ac.th

Received: 29 Oct 2021; Received in revised form: 03 Dec 2021; Accepted: 11 Dec 2021; Available online: 17 Dec 2021

(C)2021 The Author(s). Published by Infogain Publication. This is an open access article under the CC BY license

(https://creativecommons.org/licenses/by/4.0/).

\begin{abstract}
This study has examined how Singapore Airlines, a major global airline, manages its energy in an environmentally sustainable manner. The research used an in-depth qualitative longitudinal research design. The study period was from 2010/2011 to 2020/2021. Singapore Airlines four key energy sources are aircraft jet fuel, electricity, diesel, and petrol. The airline's passenger aircraft jet fuel consumption grew in line with its expansion of services and aircraft fleet. The airline's freighter aircraft fleet consumption exhibited a general downward trend. The annual electricity consumption displayed a general downward trend and benefited from the energy saving measures introduced by the airline over the study period. Diesel consumption grew in line with ground service equipment (GSE) energy requirements. The airline's annual petrol consumption fluctuated over the study period reflecting differing fuel requirements. Throughout the study period, Singapore Airlines implemented many energy efficiency measures. These measures include an aircraft weight reduction program, the installation of extensive light emitting diode (LED) lighting, the installation of more energy efficient plant and equipment, the installation of more energy efficient heat exchange system at its Silver Kris Lounge at Changi Airport, the upgrading of lifts with a more efficient model that had a Variable Voltage Variable Frequency (VVVF) motor, the installation of a large scale photovoltaic $(P V)$ system, a computer system that optimizes the maximum zero fuel weight $(M Z F W)$ of its aircraft fleet, the use of lightweight catering items, the use of light weight aircraft containers, the use of sustainable aviation fuel, and the use of fixed electrical ground power and preconditioned air units at airports where its aircraft have night layovers or long transits.
\end{abstract}

Keywords-Airlines, case study, energy, Singapore Airlines, sustainable airline energy management

\section{INTRODUCTION}

Airlines are one the most important actors in the global air transport industry value chain. The principal services provided by airlines are the transportation of passengers and air cargo. Other important activities undertaken by airlines include aircraft and ground service equipment (GSE) maintenance, aircraft ground handling and, in some instances, flight catering. Airlines are very energy intensive (Baxter et al., 2021). The largest energy requirement for an airline is typically jet fuel. The airline ground-based facilities and buildings also consume large amounts of electricity. In the case where an airline performs aircraft ground handling services then the ground service equipment (GSE) required for this function is also energy intensive. Ground service equipment (GSE) refers to vehicles and equipment that are used in the airport precinct to service whilst they are at the gate in between flights (Hazel et al., 2011).

In recent times, airlines have implemented a range of strategies and measures to sustainably manage their energy consumption. This sustainable energy management is playing a key role in mitigating airlines adverse impact on climate change and global warming (Baxter et al., 2021). To help reduce their energy jet fuel consumption, airlines are acquiring and deploying next generation, highly fuelefficient aircraft such as the Airbus A350-900XWB and the Boeing 787 (Aircraft Commerce, 2016). The concerns related to climate change and energy supply have resulted 
in the production of more sustainable aviation fuels (Brooks et al., 2016). Accordingly, sustainable aviation fuels are increasingly being regarded as an ideal option for the airline industry to achieve large, near-term emissions reductions (Staples et al., 2014). Thus, as part of their sustainability policies, airlines are increasing their use of sustainable aviation fuels (Alam et al., 2021; Michaga et al., 2021; Rice et al., 2020).

In this study, Singapore Airlines, a major global fullservice network airline, was selected as the case airline due to its long-term commitment to sustainable energy management. The sustainable management of its energy consumption is a key part of the airline's sustainability policy The objective of this paper is to analyze how Singapore Airlines manages its aircraft fuel and groundbased facility energy consumption. A second objective is to examine the role that renewable energy plays in the airline's energy policy. A final objective of the study is to examine the energy savings measures implemented by Singapore Airlines to mitigate its energy consumption. The study period was from $2010 / 2011$ to $2020 / 2021$.

The remainder of the paper is organized as follows: the literature review is presented in Section 2, and this sets the context for the Singapore Airlines case study. The research method used in the study is presented in Section 3. The case study is presented in Section 4. Section 5 presents the key findings of the study.

\section{BACKGROUND}

\subsection{Airline Jet Fuel Consumption}

As previously noted, the global airline industry is highly energy intensive (Baxter et al., 2021). Jet fuel accounts for the major share of an airline's energy consumption. There are various types of jet fuel used in the airline industry as well as for military aviation. During the 1960s, Jet-A fuel became the standard fuel used in the United States and by many commercial airlines (Brooks et al., 2016). This type of fuel was selected over the more highly flammable JP-4 for passenger safety reasons (Yildirim \& Abanteriba, 2012). Jet A-I fuel is available globally, including in the United States (Brooks et al., 2016). Jet fuel typically represents the highest cost for an airline (Turner \& Lim, 2015; Vasigh \& Rowe, 2020).

\subsection{Aircraft Fuel Efficiency}

Increasing environmental concerns have drawn the significant attention of the air transport industry towards the requirement for judicious use of aviation fuel. Consequently, both economic and environmental sustainability concerns have led to dramatic progress in aviation fuel efficiency improvements over the past few decades (Singh et al., 2018).

In recent times, both airlines and the aircraft manufacturers have invested in new technologies and strategies to reduce aircraft fuel consumption and the concomitant aircraft emissions. Aircraft fuel has a close relationship with the emissions of carbon dioxide $\left(\mathrm{CO}_{2}\right)$ and other gases that result in climate change (Zou et al., 2016).

At a global level, the peak airline industry body - the International Air Transport Association (IATA) - have recognized the requirement to address the global challenge of climate change and has subsequently adopted a set of ambitious targets to mitigate carbon dioxide $\left(\mathrm{CO}_{2}\right)$ emissions from air transport. The association has targeted an average improvement in aircraft fuel efficiency of $1.5 \%$ per year from 2009 to 2020. IATA has implemented a multi-faceted approach: the four-pillar strategy to ensure that this objective is met (International Air Transport Association, 2021b). The strategy entails:

- Improved technology, including the deployment of sustainable low-carbon fuels.

- More efficient aircraft operations.

- Infrastructure improvements, including modernized air traffic management systems.

- A single global market-based measure, to fill the remaining emissions gap (International Air Transport Association, 2021b).

The term fuel efficiency for an airline refers to the consumption between the observed and least possible volume of fuel consumed in the production of a given level of output for the airline. Due to the complexity of airline operations, fuel efficiency is dependent upon a range of factors including aircraft size, market characteristics (short-haul versus long-haul services), service network structure (hub-and-spoke or point-to-point [P2P]), and so forth (Zou et al., 2016, p. 320). Fuel efficiency is also largely dependent upon aircraft fuel burn, the average aircraft speed, and other technical design factors. It is important to note that fuel efficiency can be controlled by an airline by the flying techniques that are employed, the distances flown, as well as other variables (Vasigh et al., 2012).

There are four methods available to assess airline fuel efficiencies. The method relevant to this study is ratiobased, which is the typically used metric in the airline industry, to determine airline fuel or environmental performance. When using this metric, fuel efficiency is measured as the ratio of fuel consumed to the output produced by the airline (Zou et al., 2016). 


\subsection{Airline Ground Service Equipment (GSE) Energy Consumption}

To perform ground handling services of aircraft when they are being serviced on the ground in between flights, sophisticated technical equipment is required to perform the aircraft turnaround handling (Kazda \& Caves, 2015; Roberts, 2018). The ground service equipment (GSE) used in servicing an aircraft includes push-back tugs, lower deck loaders, (main deck loaders for freighter aircraft), toilet and water truck, tugs (for towing cargo to and from the air cargo terminal and for towing baggage to and from the airport's baggage makeup area), aircraft container and pallet dollies, ground power unit, aircraft tail stand (for freighter aircraft), and aircraft bulk hold loaders. This ground service equipment is generally powered by diesel or petrol engines. Vehicles used by airlines are also often petrol-powered (Baxter et al., 2021).

It is important to note that during the aircraft ground handling function the ground service equipment (GSE) will have periods when their engine is in idle mode. Thus, to reduce fuel consumption, and hence, reduce harmful emissions, the idle rotation speed should be as low as possible (Mu \& Tang, 2019).

\subsection{Airline Property and Facilities Energy Consumption}

To support their operations, airlines typically have extensive ground-based properties and facilities. These buildings include office buildings, aircraft and ground service equipment (GSE) maintenance facilities and hangars, air cargo terminals, and flight catering centres. Consequently, airlines require a reliable and highly efficient source of energy to power their airport and nonairport located buildings, facilities, and equipment. Electrical power is also required to run machinery, heating, ventilating, and air conditioning (HVAC) systems, building lighting, computers and so forth (Baxter et al., 2021). Aside from leasing airport terminal(s), airlines can potentially be one of several tenants in other airportlocated multi-tenant buildings (Crider et al., 2011). Airports are very energy-intensive areas (Baxter et al., 2018; Ortega Alba \& Manana, 2017; Sreenath et al., 2021). Thus, an airline's airport operations can be extremely energy intensive (Baxter et al., 2021).

As part of their sustainability measures, some airlines have installed photovoltaic (PV) solar systems. As will be noted in the case study, Singapore Airlines is one such airline that has installed a large photovoltaic (PV) solar system. The use of renewable energy resources has provided users with favorable environmental related advantages. Green energy produces no greenhouse gas (GHG) emissions from the combustion of fossil fuels. Consequently, this reduces some forms of harmful air pollution (International Renewable Energy Agency, 2021; United States Environmental Protection Agency, 2021). In addition, the use of green or renewable energy sources provides a firm or user with an important opportunity to optimize energy efficiency (Arman et al., 2013). Also, renewable energy sources normally have very little waste (Yerel Kandemir \& Yayli, 2016).

\section{RESEARCH METHODOLOGY}

\subsection{Research Method}

This study used a qualitative longitudinal research design (Derrington, 2019; Hassett \& Paavilainen-Mäntymäki, 2013; Neale, 2018). Qualitative longitudinal research aims to expand and develop theories (Derrington, 2019). The researcher's role when conducting case study research is to expand and generalize theories (analytical generalization). The researcher does not enumerate frequencies or makes any statistical generalizations (Rahim \& Baksh, 2003).

\subsection{Data Collection}

The data used in the study was obtained from a range of documents, company materials available on the internet and records as sources of case evidence. Documents included the Singapore Airlines annual sustainability reports, and the airline's websites. An extensive search of the leading air transport journals and magazines was also conducted in the study.

The key words used in the database searches included "Singapore Airlines sustainability policy", "Singapore Airlines annual passenger aircraft fleet fuel consumption", "Singapore Airlines passenger aircraft fleet annual fuel productivity ratio", "Singapore Airlines annual freighter aircraft fleet fuel consumption", "Singapore Airlines Cargo freighter aircraft fleet annual fuel productivity ratio", "Singapore Airlines annual diesel consumption", "Singapore Airlines annual electricity consumption", "Singapore Airlines annual electricity intensity ratio", "Singapore Airlines annual petrol consumption", and "Singapore Airlines energy conservation measures".

This study used secondary data. The three principles of data collection as suggested by Yin (2018) were followed: the use of multiple sources of case evidence, creation of a database on the subject and the establishment of a chain of evidence.

\subsection{Data Analysis}

The data collected for the case study was examined using document analysis. Document analysis is quite commonly used in case studies. Document analysis focuses on the information and data from formal documents and a firm's 
records that are collected by a researcher(s) when conducting their case study (Andrew et al., 2011; Yin, 2018). Following the recommendations of Scott (2004, 2014) and Scott and Marshall (2009), the study's documents were examined according to four criteria: authenticity, credibility, representativeness and meaning.

The document analysis was undertaken in six distinct stages:

- Phase 1: The first phase involved planning the types and required documentation and their availability for the study.

- Phase 2: The data collection phase involved sourcing the documents and developing and implementing a scheme for the document management.

- $\quad$ Phase 3: The collected documents were examined to assess their authenticity, credibility and to identify any potential bias.

- Phase 4: The content of the collected documents was carefully examined, and the key themes and issues were identified.

- $\quad$ Phase 5: This phase involved the deliberation and refinement to identify any difficulties associated with the documents, reviewing sources, as well as exploring the documents content.

- $\quad$ Phase 6: In this phase the analysis of the data was completed (O'Leary, 2004, p. 179).

Following the guidance of Yin (2018), the study's documents were downloaded and stored in a case study database. All the documents gathered for the study were all written in English. Each document was carefully read, and key themes were coded and recorded in the case study research framework (Baxter, 2021).

\section{RESULTS}

\subsection{A Brief Overview of Singapore Airlines}

The origins of Singapore Airlines date back to 28 January 1972. Singapore Airlines was established following the formation of Singapore as a Republic. Following Singapore's new republic status, Malaysia-Singapore Airlines (MSA) was divided into two individual airlines. These airlines subsequently became the national flag carriers of Singapore and Malaysia, respectively (Chant, 1997). Singapore Airlines began its commercial operations on 1 October 1972 (Green \& Swanborough, 1975). Upon beginning its commercial operations, Singapore Airline served the same international destinations that had been previously served by Malaysia-Singapore Airlines (MSA).
At this time, Singapore Airline operated a fleet of Boeing B707 and Boeing B737 aircraft (Chant, 1997).

A key milestone occurred on 2 April 1973, when Singapore Airlines began daily flights between Singapore and London. On 31 July 1973, the airline commenced a major expansion program following the delivery of its first wide body aircraft type, the four-turbofan powered Boeing B747-212B aircraft. The airline also commenced operating another wide body aircraft, the McDonnell-Douglas DC1030. These aircraft were operated on the airline's mediumand-high density air routes (Chant, 1997). In the latter years of the 1970s, Singapore Airlines commenced services across the Pacific, terminating at San Francisco (Brimson, 1985).

On 20 December 1980, Singapore Airlines received its first Airbus A300B4-203 aircraft. Following its introduction into commercial service, this aircraft type complemented the Boeing B747-212B and McDonnell Douglas DC10-30 aircraft (Chant, 1997). Another key milestone occurred on the 15th of October 2007 when Singapore Airlines took delivery of its first Airbus A380 aircraft. Singapore Airlines was the first airline in the world to operate the Airbus A380 aircraft (Simons, 2014). The airline operated the first commercial Airbus A380 service from Singapore to Sydney and return in October 2007 (Simons, 2014; Sloan, 2019).

At the time of the present study, Singapore Airlines operated a modern passenger fleet of 113 aircraft and had outstanding orders for a further 87 aircraft. SIA Cargo operated a fleet of 7 Boeing B747-400 freighter aircraft, which had an average fleet age of 17 years and four months. The Singapore Airlines Group comprises the wholly owned subsidiaries SilkAir, Scoot Airways, and SIA Cargo (Singapore Airlines, 2021). On 25 July 2017, Scoot and Tigerair, the SIA Group low-cost carriers, were officially merged into a single entity that retained the Scoot brand (Gupta Kapoor, 2017; Ong, 2017; Singapore Airlines, 2019). Singapore Airlines became a member of the Star global passenger airline alliance in 2000 (Heracleous \& Wirtz, 2012; Iatrou \& Alamdari, 2005; Ramaswamy, 2002).

In February 2021, Singapore Airlines officially commenced the process of integrating its subsidiary SilkAir into its operations as part of merger plans between the two airlines (Centre for Aviation, 2021).

Figure 1 presents Singapore Airlines annual enplaned passengers and revenue passenger kilometres performed (RPKs) for the period covering the financial years 2010/2011 to 2020/2021. One passenger enplanement measures the embarkation of a revenue passenger, whether originating, stop-over, connecting or returning (Holloway, 
2016). One revenue passenger kilometre (RPK) is one passenger transported one kilometre (Belobaba, 2016; Gillen, 2017). Over the period FY2010/2011 to 2019/2020, Singapore Airlines enplaned passengers and RPKs showed quite consistent growth (Figure 1). Figure 1 shows, however, that there was a very steep decline in both the annual number of enplaned passengers and RPKs in 2020, which were both adversely impacted by the global Covid 19 pandemic. In 2020, the COVID-19 pandemic caused a decline in economic activity around the world. This decline in economic activity caused a major disruption in the air travel market supply and demand chain (Dube et al., 2021). As a result, the COVID 19 related restrictions had a very adverse impact on global airline passenger demand, and thus, on the total number of revenue passenger kilometres performed (RPKs) by the world's airlines in 2020 (International Air Transport Association, 2021a).

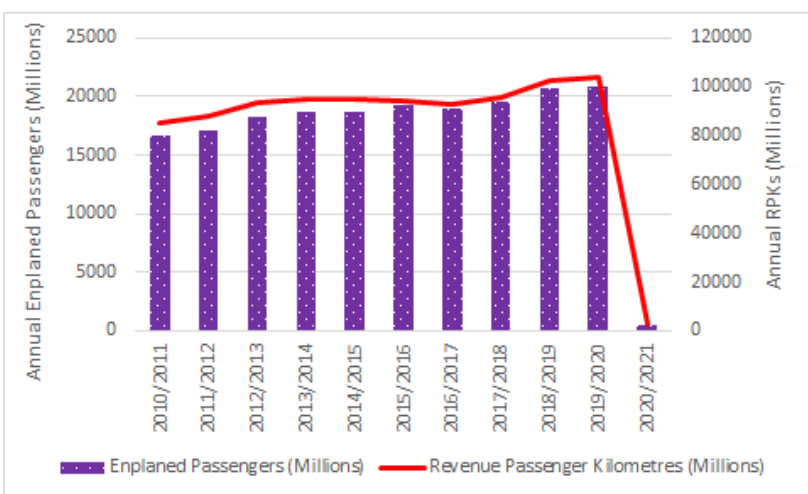

Fig.1: Singapore Airlines annual enplaned passengers and revenue passenger kilometres performed: 2010/11-

2020/21. Note: Financial years from 1 April to 31 March.

Source: Data derived from Singapore Airlines (2013, 2016, 2021).

\subsection{Singapore Airlines Environmental Policy}

Singapore Airlines has implemented a very comprehensive environment and sustainability related policy that is underpinned by four key pillars.

Pillar One: Improved technology: Singapore remains committed to its long-held policy of operating a modern and fuel-efficient fleet (Singapore Airlines, 2019). Singapore Airlines took delivery of its first Boeing 787-10 aircraft on March 25, 2018 (Field, 2018; Singapore Airlines, 2018). On September 22, 2018, Airbus delivered the first A350-900 Ultra Long Range (ULR) aircraft to Singapore Airlines (Airbus, 2018). As of 31 March 2021, Singapore Airlines operated a fleet of 113 aircraft, with an average age of five years and one month. In addition, the airline had 12 Airbus A350-900XWB, 31 Boeing 777-9s, 15 Boeing 787-10s, and 31 Boeing 737-8 MAX aircraft on firm order (Singapore Airlines, 2021). As part of its environmental policy, Singapore Airlines makes investments in engineering improvement packages for its aircraft airframes and engines. These improvements help to reduce drag and whilst at the same time improve engine efficiency, and thus, enhance fuel efficiency (Singapore Airlines, 2021).

Pillar Two: Operational measures: Importantly, as previously noted, Singapore Airlines maintains a modern and fuel-efficient fleet. As of 31 March 2021, the airline was operating 52 Airbus A350-900XWB aircraft. The Airbus A350-900XWB aircraft is acknowledged for its improved operating efficiency (Singapore Airlines, 2019). The Airbus A350-900XWB aircraft offers a $25 \%$ improvement in fuel efficiency and a $25 \%$ lower seat-mile (seat kilometre) cost when compared to its aluminumbased long-range competitors, such as the Boeing B777 aircraft (Otley, 2019). At the time of the present study, Singapore Airlines operated a fleet of fifteen Boeing 78710 aircraft (Singapore Airlines, 2021). The Boeing 787-10 aircraft burns $20 \%$ less fuel (Boeing, 2021). A key focus of the airline's environmental policy is on improving aircraft fuel productivity through the implementation of "green" operations and by reducing fuel usage through highly efficient aircraft weight management together with the optimization of flight routes (Singapore Airlines, 2021).

Pillar Three: Improved infrastructure: Infrastructure improvements in the air transport industry present an opportunity for airlines to reduce both fuel use and carbon dioxide $\left(\mathrm{CO}_{2}\right)$ emissions. Such improvements can be achieved from the optimization of air routes through efficient air traffic control management. Singapore Airlines collaborates with Air Traffic Management stakeholders to investigate new ways to improve and enhance airspace incremental efficiency (Singapore Airlines, 2019, 2021).

Pillar Four: Global Market-Based Measure (MBM): Singapore Airlines recognizes that the International Civil Aviation Organization (ICAO) CORSIA scheme will play an essential role in achieving carbon neutral growth in a cost-efficient manner. As such, the company fully supports the ongoing efforts towards meeting the requirements in the ICAO CORSIA Monitoring, Reporting and Verification system of carbon emissions. As of 1 January 2019, Singapore Airlines commenced the monitoring and reporting of its carbon dioxide $\left(\mathrm{CO}_{2}\right)$ emissions on an annual basis. Furthermore, Singapore Airlines will voluntarily participate in the ICAO CORSIA program from 2021 to 2026, following which the scheme becomes mandatory (Singapore Airlines, 2019).

Singapore Airlines is dedicated to its long-term responsibility to protect the environment while delivering 
air transportation services that are of the highest quality. The airline has introduced a range of programs to enable the company to implement sustainable practices across its operations in a responsible manner. The airline actively manages issues such as carbon dioxide $\left(\mathrm{CO}_{2}\right)$ emissions, noise, waste, as well as energy and water consumption. Singapore Airlines continues to explore new sustainable practices across all areas of its operations. The company has adopted the International Air Transport Association (IATA) four-pillar strategy to address climate change, and, as a result, it seeks opportunities to reduce the carbon footprint of its operations. The airline also promotes ecofriendly habits among its employees and stakeholders. In addition, Singapore Airlines raises the awareness on the importance of taking action to reduce its impact on the environment (Singapore Airlines, 2020). Singapore Airlines became a signatory to the Ten Principles of the United Nations Global Compact in 2018. Singapore Airlines Engineering Division and Flight Operations Division have implemented an ISO 14001:2015 Environmental Management System (Singapore Airlines, 2021). ISO 14001 is a global meta-standard for implementing Environmental Management Systems (EMS) (Dentch, 2016; Grover \& Grover, 2017; Heras-Saizarbitoria et al., 2011).

\subsection{Annual Aircraft Fuel Consumption and Fuel Efficiency}

Singapore Airlines passenger aircraft fleet annual fuel consumption (million/AG) and the year-on-year change for the period 2010/11 to 2020/21 is presented in Figure 2. As can be observed in Figure 2, Singapore Airlines annual passenger aircraft fleet fuel consumption (American gallons) has largely exhibited an upward trend reflecting the growth in services and in the aircraft fleet. This overall upward trend is demonstrated by the year-on-year percentage change line graph, which is more positive than negative, that is, more values are above the line than below. Figure 2 shows that there was a pronounced reduction in jet fuel consumption in 2020 (-78.22\%), which was due to the lower level of operations because of the covid 19 pandemic. The other annual decrease in jet fuel consumption was recorded in the 2014/2015 financial year when the annual fuel consumption decreased by $1.96 \%$ on the previous year's levels (Figure 2).

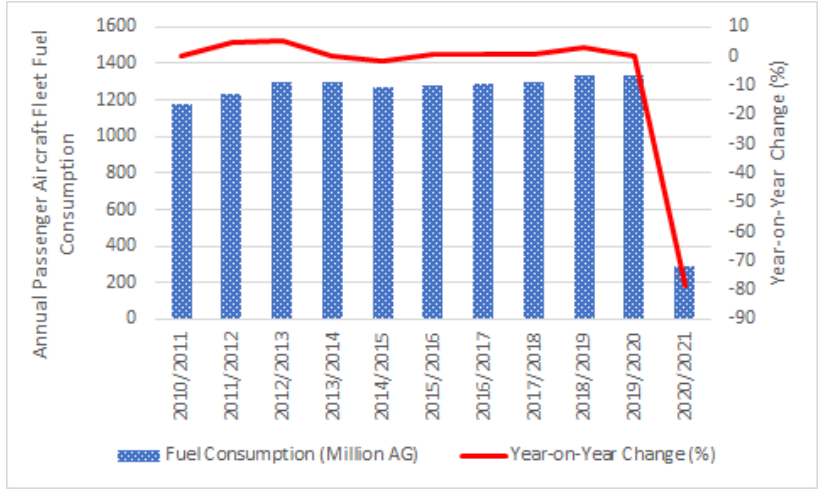

Fig.2: Singapore Airlines annual passenger aircraft fleet total annual fuel consumption (million/AG) and year-onyear change (\%): 2010/11-2020/21. Source: Data derived

from Singapore Airlines (2013, 2014, 2017, 2021).

Figure 3 presents Singapore Airlines passenger aircraft fleet annual fuel productivity ratio (LTK/AG) and the year-on-year change (\%) for the period 2010/11 to 2020/21. According to CBS Netherlands (2021), a load tonne kilometre (LTK) is a "unit of measurement for transport capacity, representing the transport of a tonne (1000 kilograms) of load capacity over one kilometre". As can be observed in Figure 3, the airline's passenger fleet fuel productivity ratio (LTK/AG) remained relatively constant throughout the study period. Over the study period, Singapore Airlines expanded its passenger services, and thus, flew more load tonne kilometres. The airline has been able to achieve this growth whilst also maintaining its fuel productivity ratio at a relative constant value, which is a favorable outcome. In addition, the airline has added more next generation, fuel efficient aircraft, such as, the Airbus A350-900XWB and the Boeing 787-10, to its fleet in the latter years of the study; these aircraft are more fuel efficient when compared to the aircraft types that they have replaced. The lowest annual level was recorded in the 2020/2021 financial year $(8.3$ LTK/AG), whilst the highest level was recorded in the 2018/2019 financial year (10.74 LTK/AG). There were five years in the study period where this ratio declined on a year-on-year basis. These decreases occurred in the 2011/2012 (-0.98\%), 2012/2013 (-0.59\%), 2015/2016 ($0.29 \%), 2019 / 2020(-1.58 \%)$, and 2020/2021 (-21.47\%) financial years, respectively (Figure 3 ). The largest single annual decrease in this ratio was recorded in the 2017/2018 $(+4.02 \%)$ financial year (Figure 3$)$. 


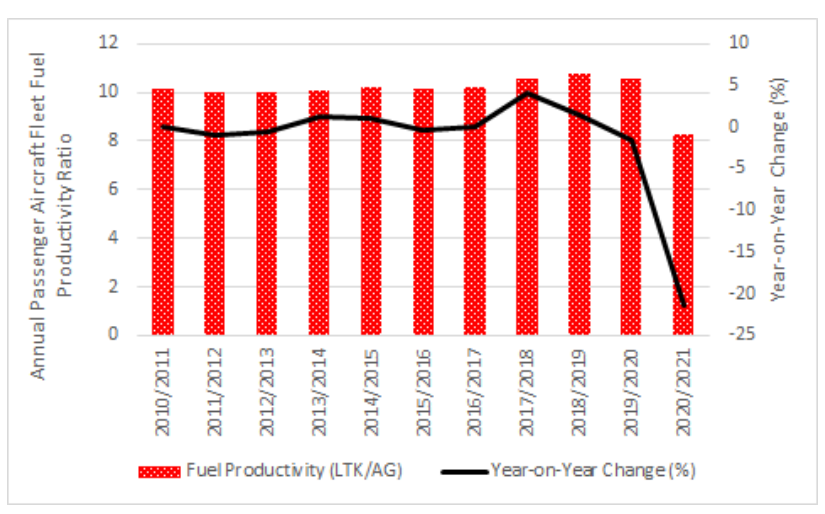

Fig.3: Singapore Airlines annual passenger aircraft fleet fuel productivity ratio and year-on-year change (\%): 2010/11-2020/21. Source: Data derived from Singapore Airlines (2013, 2014, 2017, 2021).

The carriage of air cargo is also a core business activity of Singapore Airlines. The airlines air cargo division, SIA Cargo, operates a fleet of seven Boeing B747-400 freighter aircraft. A freighter aircraft is an aircraft that has been expressly designed or which has been converted to transport air cargo, express, and so forth, rather than passengers (Wensveen, 2016). Singapore Airlines Cargo freighter aircraft fleet annual fuel consumption (million/AG) and the year-on-year change (\%) from 2010/11 to 2020/21 is presented in Figure 4. As can be observed in Figure 4, Singapore Airlines freighter aircraft fuel consumption has largely displayed a downward trend over the study period. This overall downward trend is demonstrated by the year-on-year percentage change line graph, which is more negative than positive, that is, more values are below the line than above. Figure 4 shows that Singapore Airlines freighter aircraft fuel consumption declined from a high of 182.02 million/AG in the 2010/2011 financial year to a low of 92.8 million/AG in the 2019/2020 financial years, respectively. There were two years in the study period where Singapore Airlines freighter aircraft fleet annual fuel consumption increased on a year-on-year basis. These increases occurred in the $2015 / 2016(+4.17 \%)$ and 2020/2021 (+17.02\%) financial years, respectively. The overall downward trend in freighter aircraft fleet fuel consumption is most favourable, particularly as Singapore Airlines Cargo annual freight tonnages remained relatively constant over the study period. This suggests Singapore Airlines Cargo has been able to accommodate its tendered air cargo traffic whilst at the same time reducing its freighter fleet fuel consumption.

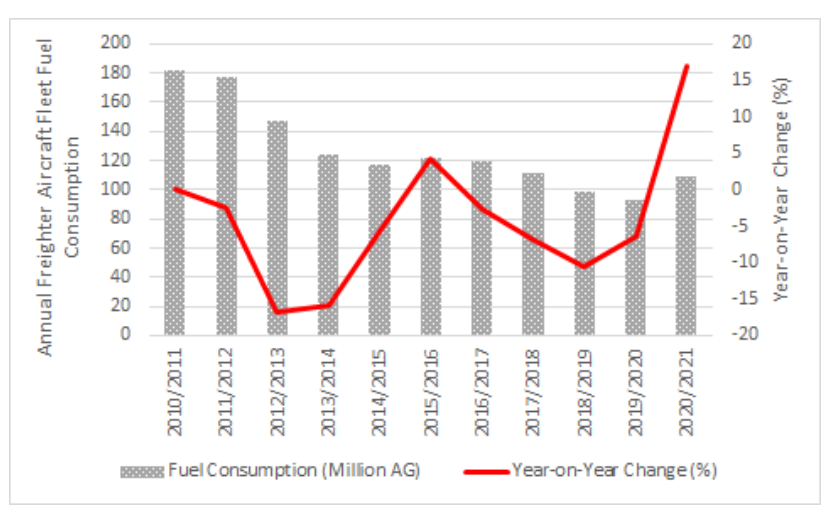

Fig.4: Singapore Airlines annual freighter aircraft fleet total annual fuel consumption (million/AG) and year-onyear change (\%): 2010/11-2020/21. Source: Data derived

from Singapore Airlines (2013, 2014, 2017, 2021).

Figure 5 presents Singapore Airlines Cargo freighter aircraft fleet annual fuel productivity ratio (LTK/AG) and the year-on-year change (\%) for the period 2010/11 to 2020/21. As can be observed in Figure 5, Singapore Airlines Cargo freighter aircraft fleet annual fuel productivity ratio (LTK/AG) oscillated throughout the study period. This ratio exhibited a downward trend from 2010/2011 to 2015/2016, decreasing from 17.92 LTK/AG in the 2010/11 financial year to a low of 16.4 LTK/AG in the 2015/2016 financial year. This was followed by an upward trend with this ratio increasing from 16.4 LTK/AG in the 2015/2016 financial year to $17.68 \mathrm{LTK} / \mathrm{AG}$ in the $2017 / 2018$ financial year. The ratio decreased on a yearon-year basis in the 2017/2018 (-4\%), 2018/2019 ($2.43 \%)$, and $2019 / 2020(-6.37 \%)$ before once again returning to positive growth in the 2020/2021 financial year $(+3.4 \%)$ (Figure 5$)$.

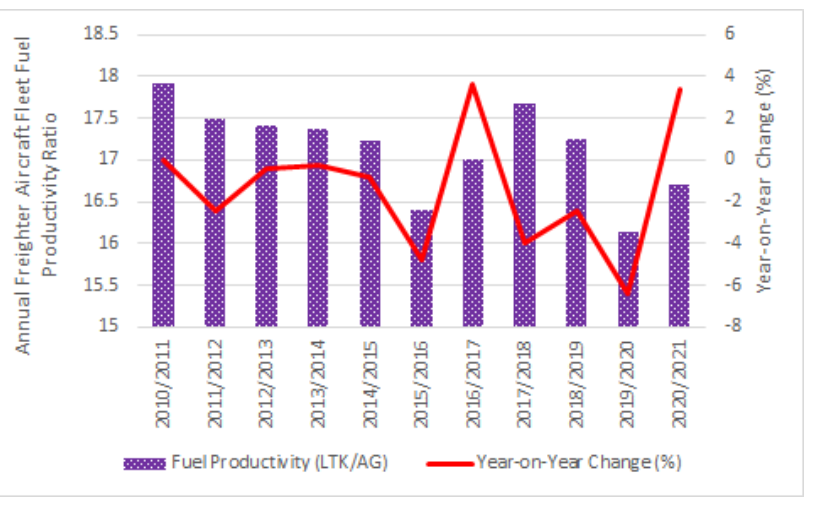

Fig.5: Singapore Airlines annual freighter aircraft fleet fuel productivity ratio and year-on-year change (\%): 2010/11-2020/21. Source: Data derived from Singapore Airlines (2013, 2016, 2021). 


\subsection{Singapore Airlines Facilities and Ground Service Equipment (GSE) Energy Consumption}

\subsubsection{Annual Diesel Consumption}

Singapore Airlines annual diesel consumption (litres) and the year-on-year change $(\%)$ for the period 2010/11 to 2020/21 is depicted in Figure 6. As can be observed in Figure 6, Singapore Airlines annual diesel consumption has displayed an upward trend, increasing from 3,376 litres in the 2010/2011 financial year to a high of 10,152 litres in the 2020/2021 financial year. This overall upward trend is demonstrated by the year-on-year percentage change line graph, which is more positive than negative, that is, more values are above the line than below. Figure 6 shows that there was a pronounced spike in the airline's diesel consumption in the $2018 / 2019(+105.92 \%)$ and 2019/2020 $(+91.98 \%)$ financial years. There was a significant decrease in diesel consumption in the 2017/2018 ($49.24 \%$ ) financial year (Figure 6). There were also other smaller decreases in diesel consumption recorded in the $2011 / 2012(-2.05 \%), 2012 / 2013(-4.47 \%)$, and 2014/2015 $(-9.57 \%)$ financial years, respectively. it is important to note that Singapore Airlines has grown its operations over the study period and the overall upward trend in diesel consumption reflect its ground service equipment (GSE) and vehicle consumption patterns.

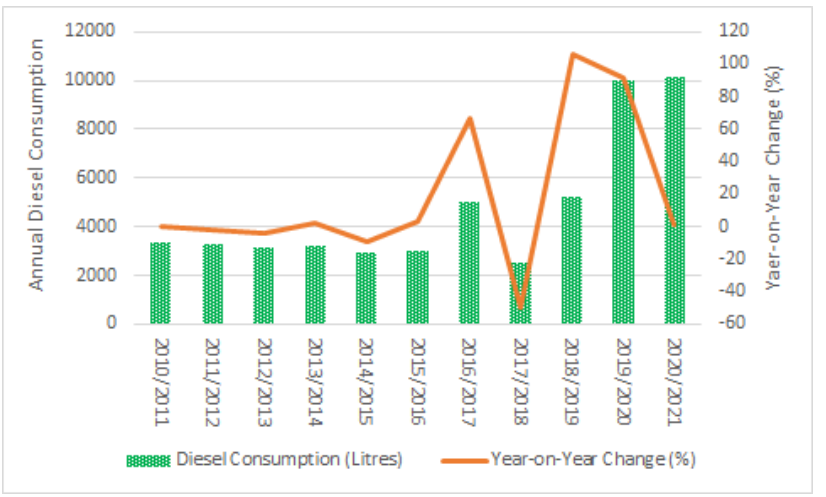

Fig.6: Singapore Airlines annual diesel consumption (litres) and year-on-year change (\%): 2010/11-2020/21.

Source: Data derived from Singapore Airlines (2013, 2014, 2017, 2021).

\subsubsection{Annual Electricity Consumption}

Singapore Airlines purchased electricity consumption is for four of the airline's properties - Airline House (ALH), SIA Training Centre (STC), TechSQ (TSQ), SIA Supplies Centre (SSC) and offices. Singapore Airlines annual electricity consumption $(\mathrm{GWh})$ and the year-on-year change (\%) from the 2010/11 financial year to the 2020/21 financial year is presented in Figure 7. As can be observed in Figure 7, Singapore Airlines annual electricity consumption has displayed a general downward trend, decreasing from 59.9 GWh in the 2021/2011 financial year to a low of $20.8 \mathrm{GWh}$ in the $2020 / 2021$ financial year. This overall downward trend is demonstrated by the year-onyear percentage change line graph, which is more negative than positive, that is, more values are below the line than above. Figure 7 shows that there were two years in the study period where Singapore Airlines electricity consumption increased on a year-on-year basis. These increases occurred in the 2011/2012 (+1.00\%) and $2018 / 2019(+1.07 \%)$ financial years, respectively. There was a very pronounced decrease in electricity consumption in the 2016/2017 financial year, when it decreased by $45.68 \%$ on the previous year's level. There was another significant decrease in the airline's electricity consumption in the 2020/2021 financial year, when it decreased by $25.44 \%$ on the $2019 / 2020$ levels. Overall, this is a very favorable trend and suggests that the energy savings measures outlined below have had a very favorable impact on Singapore Airlines annual electricity consumption.

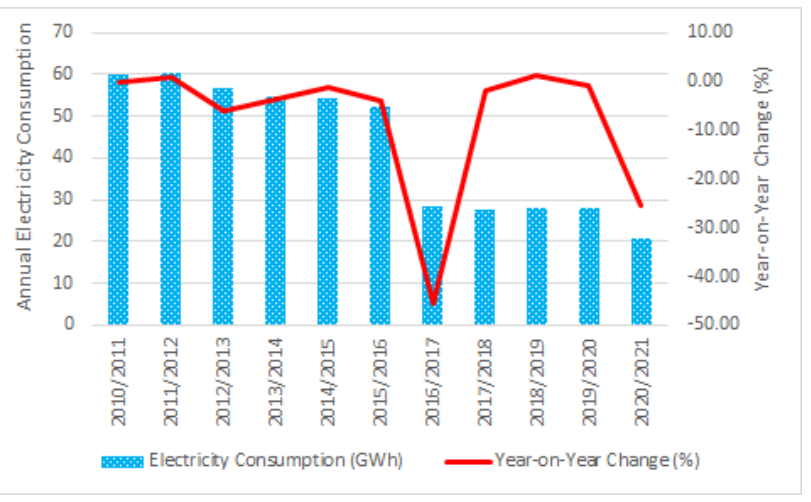

Fig.7: Singapore Airlines annual electricity consumption (GWh) and year-on-year change (\%): 2010/11-2020/21.

Source: Data derived from Singapore Airlines (2013, 2014, 2017, 2021)

Figure 8 presents Singapore Airlines annual electricity intensity ratio and the year-on-year change $(\%)$ from 2016/17 to 2020/21. Singapore Airlines annual electricity intensity ratio decreased from a high of $121.95 \mathrm{kWh} / \mathrm{m}^{2}$ in the $2016 / 2017$ financial year to a low of $98.1 \mathrm{kWh} / \mathrm{m}^{2}$ in the 2020/2021 financial year (Figure 8). Figure 8 shows that there was just a single year in the study period when this ratio increased on a year-on-year basis. This increase was recorded in the $2018 / 2019(+1.21 \%)$ financial year. There was a pronounced decrease in this ratio in the $2020 / 2021$ financial year when it decreased by $18.48 \%$ on the 2019/2020 level (Figure 8). The general downward trend in this ratio is also a very favorable outcome and shows that Singapore Airlines is effectively managing its electricity consumption per square metre of building space. 


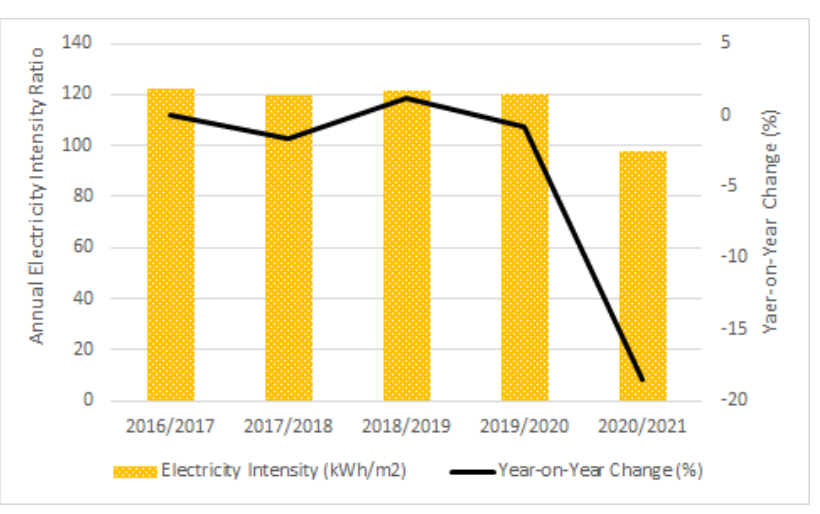

Fig.8: Singapore Airlines annual electricity intensity ratio and year-on-year change (\%): 2016/17-2020/21.Note: data prior to 2016/17 not available. Source: Data derived from Singapore Airlines (2013, 2014, 2017, 2021).

\subsubsection{Annual Petrol Consumption}

Singapore Airlines annual petrol consumption (litres) and the year-on-year change $(\%)$ for the period 2010/11 to 2020/21 is depicted in Figure 9. Figure 9 shows that Singapore Airlines annual petrol consumption has fluctuated throughout the study period reflecting varying vehicle petrol consumption patterns. During the study period, there were four years where the annual petrol consumption decreased quite significantly on a year-onyear basis. These decreases occurred in the 2012/2013 ($20.83 \%), 2013 / 2014$ (-13.59\%), 2014/2015 (-24.87\%), and 2020/2021 (-38.95\%) financial years, respectively (Figure 9). As can be observed in Figure 9, there was a significant increase in the airline's petrol consumption in the $2017 / 2018(+31.16 \%)$, and 2018/2019 (+20.26\%) financial years, which reflected greater vehicle petrol consumption in those two financial years.

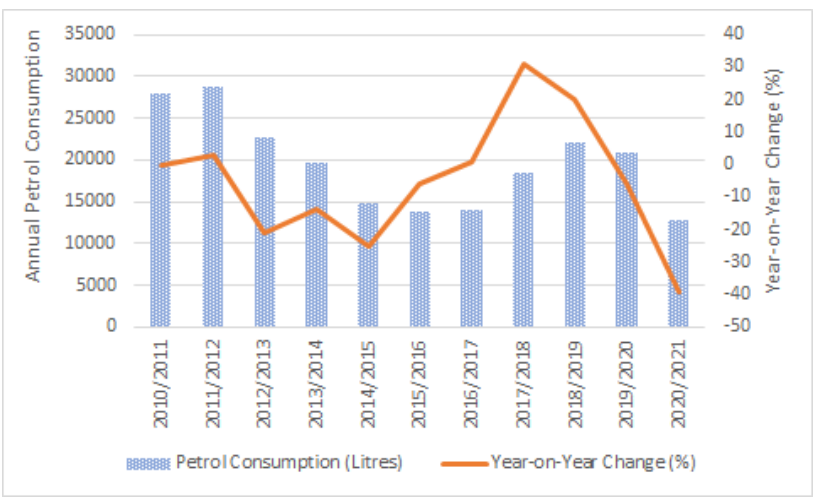

Fig.9: Singapore Airlines annual petrol consumption (litres) and year-on-year change (\%): 2010/11-2020/21.

Source: Data derived from Singapore Airlines (2013, 2014, 2017, 2021).

\subsection{Singapore Airlines Energy Conservation Measures}

4.5.1 Aircraft Weight Reduction Program
Airlines are increasingly introducing a range of measures that are designed to lower the weight of their aircraft, and hence, reduce aircraft fuel burn (Gilani \& Körpe, 2019). Singapore Airlines has implemented aircraft weight saving measures initiatives both within its group airlines and with the Original Equipment Manufacturers (OEMs). Singapore Airlines has implemented an initiative that was designed to optimize the water uplift based on flight sector requirements through a tailored potable water program. Another initiative involved the removal of unutilized overhead storage compartments located in between the galleys of the airline's Boeing 777-300ER aircraft fleet. These two initiatives saved 2,400 tonnes of jet fuel per annum (Singapore Airlines, 2017).

\subsubsection{Cleaner Energy Vehicles}

The replacement of internal combustion engine powered airport ground support vehicles and equipment with cleaner energy powered vehicles could potentially reduce carbon dioxide $\left(\mathrm{CO}_{2}\right)$, carbon monoxide $(\mathrm{CO})$, hydrocarbons $(\mathrm{HC})$, nitrogen oxides $\left(\mathrm{NO}_{\mathrm{x}}\right)$, and particulate matter (PM) (Gellings, 2011). Singapore Airlines has been cognizant of the environmental impact of fossil fuel vehicles and equipment and, as a result, in the 2020/21 financial year, Singapore Airlines installed six electric vehicles (EV) charging stations and promoted the use of electric vehicles (Singapore Airlines, 2021).

\subsubsection{Ground-Based Facilities Energy Conservation Measures}

Because of the growing problems of climate change and global warming, airlines are now actively promoting energy-savings (Tsai et al., 2014). Throughout the study period, Singapore Airlines introduced an extensive range of energy saving measures, which had a particular focus on air-conditioning, ventilation, lightings, and lifts within the company's buildings.

Singapore Airlines Office Management System (OMS) features innovative designs and best office practices that not only maximize space utilization but also reduce energy consumption (Singapore Airlines, 2015).

During the 2014/15 financial year, Singapore Airlines buildings and facilities were upgraded with more energyefficient equipment and technology. These energy efficiency measures included the upgrading of lifts with a more efficient model that had a Variable Voltage Variable Frequency (VVVF) motor, the changing of high bay lights from metal halide lamps to more energy-efficient light emitting diode (LED) lighting, the replacement of neon signs on the company's main buildings with LED technology, the installation of a heat exchange system at the SilverKris Lounge at Changi Airport, which is used to produce hot water for the showers, and the replacement of 
an old chiller system with a higher energy efficiency model. These energy saving measures amounted to 80 MWh per month (Singapore Airlines, 2015).

In the 2016/17 financial year, Singapore Airlines energy saving measures focused on the management of air conditioning systems and lighting within its buildings. A key energy saving measure implemented by the airline was the replacement of high bay lighting for hangar operations (Singapore Airlines, 2017). These measures reduced both energy consumption. In the 2017/18 financial year, Singapore Airlines continued its energy saving measures program which included the completion of replacement of high bay lights project for the airline's Hangar 1 from 1,000W sodium metal halide lamps to 400W dimmable LED high bay lights. This measure provided energy efficiency savings. Other energy efficiency measures included the ongoing replacement of Fan Coil Units (FCUs) within the company's buildings with more efficient models as well as the replacement of Computer Air-Conditioning Units (CAUs) serving the aircraft simulator computers with higher efficiency units (Singapore Airlines, 2018). In the 2018/19 financial year, Singapore Airlines conducted a feasibility study that focused on the potential use of solar energy to support the company's use of green energy to meet its buildings' energy requirements. A tender was initiated for the installation of solar panels at the airline's Head Office building in Singapore. Other energy saving measures included the progressive upgrading of air-conditioning equipment to ensure that the most energy efficient equipment is used in the company's buildings and facilities, the airline also continued the replacement of Fan Coil Units (FCUs) within its buildings with more efficient models, and the company continued to replace old light fittings with LED lighting (Singapore Airlines, 2019).

In the 2019/20 financial year, Singapore Airlines continued to implement energy reduction initiatives, and these resulted in an estimated $800 \mathrm{MWh}$ of energy savings principally through adjustments to the operating parameters of its chiller plants and air-handling units (AHU), and through the replacement of lighting with more energy efficient light-emitting diode (LED) light fittings. In addition to its energy reduction initiatives, the airline started adopting the use of renewable energy. As part of this strategy, Singapore Airlines entered into a partnership agreement with SembCorp Solar to install rooftop solar panels on three of its Singapore-based buildings: Airline House, SIA Training Centre and TechSQ. It was envisaged that the solar panels would come online in the second quarter of FY2020/21, and they would generate a projected 5,382 MWh of renewable energy annually, which is able to support up to 18 per cent of the company's buildings' electricity demand (Singapore Airlines, 2020). The installation of the solar panels on all its office buildings in Singapore was completed in the 2020/21 financial year (Singapore Airlines, 2021).

4.5.4 Improving Aircraft Maximum Zero Fuel Weights (MZFW) to Optimize Aircraft Fuel Uplift

An aircraft's maximum zero fuel weight (MZFW) is the maximum weight permitted on the aircraft before fuel is loaded (Jofré \& Irrgang, 2000). By improving the accuracy of an aircraft's MZFW, the correct amount of fuel is uplifted on a flight. This reduces the overall weight of the aircraft. Singapore Airlines has implemented a computer system to improve the MZFW accuracy of its aircraft fleet. The airline has introduced a "ZFW Monitoring Dashboard". This system enables its Airport Operations department to monitor the MZFW of its aircraft fleet more closely. In the 2019/20 financial year, the optimization of aircraft MZFW weights resulted in an estimated 1,800 tonnes of fuel savings (Singapore Airlines, 2020).

4.5.5 Reduced Engine Aircraft Taxi in Procedure at Airports

As part of their sustainability policy, Singapore Airlines has implemented a "Reduced Engine Taxi In" procedure for their aircraft fleet to optimize fuel efficiency. Upon landing at their destination, pilots can use a single engine for twin-engine aircraft, or alternatively three engines for four-engine aircraft during taxiing process (Singapore Airlines, 2018). This measure therefore reduces the fuel consumption during the aircraft taxying phase of the flight at the destination airport.

4.5.6 Removal of Economy Class Footrests in Selected Aircraft

In 2019, Singapore Airlines removed some Economy Class footrests on selected aircraft. This measure delivered a weight saving of around $200 \mathrm{~kg}$ to $300 \mathrm{~kg}$ per aircraft (Singapore Airlines, 2019). The lower aircraft weight translates into lower fuel burn.

\subsubsection{The use of aviation biofuels}

Singapore Airlines has been an active member of the "Sustainable Aviation Fuel Users Group" (SAFUG) since 2011. Singapore Airlines views sustainable aviation fuels as a key long-term measure to support the air transport industry's carbon-neutral growth goal beyond 2020. Accordingly, the airline has pledged to advance and adopt aviation biofuels produced in a sustainable way. The sustainable aviation fuels should have minimal impact on biodiversity, such fuels should meet a sustainability standard, in relation to land, water and energy use, the production of sustainable aviation fuels should not displace or compete with food crops; and these fuels should also 
provide a positive socio-economic impact (Singapore Airlines, 2019).

In addition to the use of sustainable aviation fuels on a series of "Green Flights" in 2017, Singapore Airlines commenced working with Stockholm's Swedavia Airport in 2020 on the use of sustainable aviation fuels (Becken, 2021). In January 2020, Singapore Airlines began a yearlong partnership with Swedish airport operator Swedavia. As part of Swedavia's sustainable aviation fuel (SAF) Incentive Scheme, the airline commenced using a blend of jet fuel and SAF on its flights between Stockholm and Moscow (Singapore Airlines, 2020). This arrangement between the two parties continued in the 2020/21 financial year (Singapore Airlines, 2021).

\subsubsection{The use of Lightweight Aircraft Unit Load Devices}

In recent times, airlines from all around the world have sought to minimize aircraft weight without compromising the business volume is using light weight aircraft unit load devices (ULDs) (Laniel et al., 2011). Aircraft unit load devices, or ULDs, are pallets and containers which are used to carry air cargo, mail and passenger baggage on wide-body passenger and freighter aircraft (Baxter et al., 2014; Lu \& Chen, 2011). To achieve their fuel saving objectives, in recent times airlines have acquired new light-weight composite material aircraft unit load devices (ULDs) (Bandi \& Lumia, 2013). Singapore Airlines is one such airline that has acquired light weight aircraft ULDs as a fuel saving measure (Singapore Airlines, 2021).

4.5.9 The Use of Light Weight Flight Catering Items on Regional Passenger Services

In 2020, Singapore Airlines introduced a new regional economy class menu which offered passengers additional meal choices. These were accompanied with bamboo cutlery and sustainable paper packaging. The new packaging was lighter, weighing half that of previously used plastics. This reduction in weight results in lower fuel consumption (Becken, 2021; Singapore Airlines, 2021).

\subsubsection{The Use of Airport Mobile Ground Power Units}

During the time an aircraft is on the ground between flights, electrical power is required on the airport apron to enable the ground handling of the aircraft prior to engine start-up. (Ashford et al., 2013; Horonjeff et al., 2010; Kazda \& Caves, 2015). Singapore Airlines has introduced a policy where mobile ground power units and preconditioned air units are used during night layovers and long transits at airports. The use of fixed electrical ground power alleviates the reliance on its aircraft auxiliary power units (APUs) (Singapore Airlines, 2017, 2019). The use of fixed electrical ground power reduces fuel consumption as it is no longer necessary to use fuel to run the aircraft
APU. In the 2019/20 financial year, this energy conservation measure delivered an estimated 910 tonnes in fuel savings (Singapore Airlines, 2020).

\section{CONCLUSION}

The global airline industry plays a vital role in the world economy by facilitating the movement of passengers and air cargo consignments. This transportation assists the global tourism industry as well as world trade. However, airlines are very energy intensive and, as a result, airlines are now seeking ways to manage their energy consumption on a more sustainable basis. Based on its commitment to sustainably manage its operations and its energy consumption, this study selected Singapore Airlines as the case airline. The study period was from 2010/2011 to $2020 / 2021$. The secondary data collected for the study was examined by document analysis.

Singapore Airlines has four principal energy sources. The largest energy source is the jet fuel that is required to power its fleet of passenger and freighter aircraft. The airline's second largest energy source is the electricity that is required to power its Singapore-based facilities. The airline has a fleet of ground service equipment (GSE) and vehicles that underpin its ground operations. Thus, the third largest energy source for Singapore Airlines is the petrol used to power its fleet of vehicles. The final energy source is the diesel used to power its fleet of ground service equipment (GSE).

The case study found that Singapore Airlines jet fuel consumption has increased over the study period and is inline with its expansion of services and aircraft fleet. The annual fuel consumption for the passenger fleet declined very significantly in the 2020/2021 financial year due to the reduced scale of passenger operations because of the covid 19 pandemic. Air cargo is a core product of Singapore Airlines, and its freighter fleet fuel consumption exhibited a downward trend over the study period. This was a favourable outcome as the airline was able to satisfy its air cargo shippers' supply chain transportation requirements whilst at the same time reducing the annual consumption of jet fuel used to power its fleet of dedicated freighter aircraft. The case study revealed that the airline's diesel consumption had grown over the study period, increasing from 3,376 litres in the 2010/2011 financial year to a high of 10,152 litres in the 2020/2021, with the overall increase reflecting greater fuel consumption patterns. Singapore Airlines annual petrol consumption oscillated over the study period, with the highest annual consumption recorded in the 2011/2012 financial year (28,800 litres) and the lowest annual consumption in the 2020/2021 financial year (12,740 litres), respectively. 
Singapore Airlines annual electricity consumption displayed a favourable downward trend, decreasing from 59.9 GWh in the 2010/2011 financial year to a low of 20.8 GWh in the 2020/2021 financial year.

A key energy saving strategy of Singapore Airlines has been the acquisition and deployment of the latest state of the art aircraft, such as the Airbus A350-900 XWB and Boeing 787-10 aircraft. These aircraft offer greater fuel efficiency than the aircraft models that they replaced. Like many other companies, Singapore Airlines has installed a photovoltaic (PV) system and this system will be capable of generating 5,382 MWh of renewable energy annually, which is able to support up to 18 per cent of the company's buildings' electricity demand.

As previously noted, throughout the study period, Singapore Airlines implemented various energy efficiency measures. These include an aircraft weight reduction program, the installation of extensive light emitting diode (LED) lighting, the installation of more energy efficient heat exchange system at its Silver Kris Lounge at Changi Airport, the installation of more energy efficient plant and equipment, the upgrading of lifts with a more efficient model that had a Variable Voltage Variable Frequency (VVVF) motor, the installation of a large scale photovoltaic (PV) system, a computer system that optimizes the maximum zero fuel weight (MZFW) of its aircraft fleet, the use of lightweight catering items, the use of light weight aircraft unit load devices, the use of sustainable aviation fuels, and the use of fixed electrical ground power and preconditioned air units at airports where its aircraft have night layovers or long transits.

\section{REFERENCES}

[1] Airbus. (2018). First ultra-long range A350 XWB delivered to Singapore Airlines. Retrieved from https://www.airbus.com/newsroom/pressreleases/en/2018/09/first-ultra-long-range-a350-xwbdelivered-to-singapore-airlines.html.

[2] Aircraft Commerce. (2016). Fuel burn \& operating performance of the 787-8, 787-9 and A350-900. Aircraft Commerce, 108, 16-27.

[3] Alam, A., Farhad Hossain Masum, M., \& Dwivedi, P. (2021). Break-even price and carbon emissions of carinatabased sustainable aviation fuel production in the Southeastern United States. GCB-Bioenergy, 13(11), 18001813. https://doi.org/10.1111/gcbb.12888

[4] Andrew, D.P.S., Pedersen, P.M., \& McEvoy CD. (2011). Research methods and design in sport management. Champaign: Human Kinetics.

[5] Arman, H., \& Yuksel, I. (2013). Preface. In H. Arman \& I Yuksel (Eds.), New developments in renewable energy (pp. xi-xii). Rijeka: InTech.
[6] Ashford, N. J., Martin Stanton, H.P., Moore, C.A., Coutu, P., \& Beasley, J.R. (2013). Airport operations (3rd ed.). New York: McGraw-Hill.

[7] Bandi, S. \& Lumia, R. (2013). Cycle time reduction of a composite panel manufacturing line. International Journal of Mechanical Engineering and Robotics Research, 2(2), 189-203.

[8] Baxter, G. (2021). Mitigating an airport's carbon footprint through the use of "green" technologies: The case of Brisbane and Melbourne Airports, Australia. International Journal of Environment, Agriculture and Biotechnology, 6(6), 29-39. https://dx.doi.org/10.22161/ijeab.66.4

[9] Baxter, G., Kourousis, K. \& Wild, G. (2014). Fire resistant aircraft unit load devices and fire containment covers: A new development in the global air cargo industry. Journal of Aerospace Technology and Management, 6(2), 202-209. https://doi.org/10.5028/jatm.v6i2.327

[10] Baxter, G., Srisaeng, P, \& Wild, G. (2018). Sustainable airport energy management: The case of Kansai International Airport. International Journal for Traffic and Transport Engineering, 8(3), 334 - 358.

[11] Baxter, G., Srisaeng, P., \& Wild, G. (2021). A qualitative assessment of a full-service network airline sustainable energy management: The case of Finnair PLC. WSEAS Transactions on Environment and Development, 17, 167180.

[12] Becken, B. (2021). Singapore Airlines targets net zero carbon emissions by 2050 . Retrieved from https://www.businesstravelerusa.com/business-traveler-usastory/singapore-airlines-targets-net-zero-carbon-emissionsby-2050/.

[13] Belobaba, P.P. (2016). Overview of airline economics, markets, and demand. In: P. Belobaba, A. Odoni \& C. Barnhart (Eds.), The global airline industry (pp. 47-74) (2nd ed.). Chichester: John Wiley \& Sons.

[14] Boeing Commercial Airplanes. (2021). Dreamliner advantages overview. Retrieved from https://www.boeing.com/commercial/787/bydesign/\#/dreamliner-advantages-overview.

[15] Brimson, S. (1985). The airlines of the world. Sydney: Dreamweaver Books.

[16] Brooks, K.P., Snowden-Swan, L.J., Jones, S.B., Butcher, M.G., Lee, G.S.J, Anderson, D.M., Frye, J.G., Holladay, J.G., Owen, J., Harmon, L., Burton, F., Palou-Rivera, L., Plaza, J., Handler, R., \& Shonnard, D. (2016). Low-carbon aviation fuel through the alcohol to jet pathway. In C. Chuck (Ed.), Biofuels for aviation: Feedstocks, technology, and implementation (pp. 109-146). London: Academic Press.

[17] CBS Netherlands. (2021). Load capacity tonne-kilometre. Retrieved from https://www.cbs.nl/en-gb/onzediensten/methods/definitions/load-capacity-tonnekilometre\#: :text=Unit $\% 20$ of $\% 20$ measurement $\% 20$ for $\% 20 \mathrm{t}$ ransport,load\%20capacity\%20over\%20one\%20kilometre. 
[18] Centre for Aviation. (2021). Singapore Airlines profile. Retrieved from https://centreforaviation.com/data/profiles/airlines/singapore -airlines-sq.

[19] Chant, C. (1997). Airlines of the world. London: Tiger Books International.

[20] Crider, R., Preisler, M., Autin, E., Roth, S., Armstrong, R.W., Fulton, S., Swartzlander, J., \& Tharp, G. (2011). Guidebook for developing and leasing airport property. Airport Cooperative Research Program Report 47. Washington: Transportation Research Board.

[21] Dentch, M.P. (2016). The ISO 14001:2015 handbook: Using the process approach to building an environmental management system. Milwaukee, WI: Quality Press.

[22] Derrington, M.L. (2019). Qualitative longitudinal methods: Researching implementation and change. Thousand Oaks: SAGE Publications.

[23] Dube, K., Nhamo, G., \& Chikodzi, D. (2021). COVID-19 pandemic and prospects for recovery of the global aviation industry. Journal of Air Transport Management, 92, 102022. https://doi.org/10.1016/j.jairtraman.2021.102022

[24] Field, J. (2018). Singapore Airlines receives first 787-10 Dreamliner. Retrieved from https://airwaysmag.com/airlines/singapore-airlines-receivesfirst-787-10-dreamliner/.

[25] Gellings, C.W. (2011). Saving energy and reducing $\mathrm{CO}_{2}$ emissions with electricity. Lilburn: The Fairmont Press.

[26] Gilani, M., \& Körpe, D.S. (2019). Airline weight reduction to minimize direct operating cost. In Proceedings of the 4th International Aviation Management Conference (4th INTAVIC), Ankara, Turkey, November 18-19 (pp.1-12).

[27] Gillen, D. (2017). Aviation economics and forecasting. In: L. Budd \& S. Ison (Eds.), Air transport management: An international perspective (pp. 27-45). Abingdon: Routledge.

[28] Green, W. \& Swanborough, G. (1975). The Observer's world airlines and airliners directory. London: Frederick Warne \& Co.

[29] Grover, R.C., \& Grover, S. (2017). Winning the environmental challenge with ISO 14001: 2015: Implementation of an Environmental Management System. Chennai, India: Notion Press.

[30] Gupta Kapoor, N. (2017). Scoot and Tigerair merge. Retrieved from https://www.businesstraveller.com/businesstravel/2017/07/26/scoot-tigerair-merge/

[31] Hassett, M., \& Paavilainen-Mäntymäki, E. (2013). Longitudinal research in organizations: An introduction. In M. Hasset \& E. Paavilainen-Mäntymäki (Eds.), Handbook of longitudinal research methods in organisation and business studies (pp. 1-12). Cheltenham: Edward Elgar Publishing.

[32] Hazel, R.A., Blais, J.D., Browne, T.J., \& Benzon, D.M. (2011). Resource guide to airport performance indicators. Airport Cooperative Research Program Report 19A. Washington: Transportation Research Board.
[33] Heracleous, L. \& Wirtz J. (2012). Strategy and organisation at Singapore Airlines: Achieving sustainable advantage through dual strategy. In: O. Inderwildi \& S. King (Eds.), Energy, transport, \& the environment (pp. 479-493). London: Springer.

[34] Heras-Saizarbitoria, I., Landín, G.A., \& Molina-Azorín, J.F. (2011). Do drivers matter for the benefits of ISO 14001? International Journal of Operations and Production Management, $\quad 31(2), \quad$ 192-216. https://doi.org/10.1108/01443571111104764

[35] Holloway, S. (2016). Straight and level: Practical airline economics (3rd ed.). Abingdon: Routledge.

[36] Horonjeff, R., McKelvey, F.X., Sproule, W.J., \& Young, S.B. (2010). Planning \& design of airports (5th ed.). New York: McGraw-Hill.

[37] Iatrou, K., \& Alamdari, F. (2005). The empirical analysis of the impact of alliances on airline operations. Journal of Air Transport Management, 11(3), 127-134. https://doi.org/10.1016/j.jairtraman.2004.07.005

[38] International Air Transport Association. (2021a). Airline industry statistics confirm 2020 was worst year on record. Retrieved from https://www.iata.org/en/pressroom/pr/202108-03-01/

[39] International Air Transport Association. (2021b). Fuel efficiency. $\quad$ Retrieved from https://www.iata.org/en/programs/ops-infra/fuel/fuelefficiency/.

[40] International Renewable Energy Agency. (2021). Benefits. Retrieved from https://www.irena.org/benefits.

[41] Jofré, M., \& Irrgang, M.E. (2000). Integration of cargo and passenger operations. In G.F. Butler \& M.R. Keller (Eds.), Handbook of airline operations (pp. 259-271). New York: McGraw-Hill.

[42] Kazda, A., \& Caves, R.E. (2015). Airport design and operation (3rd ed.). Bingley: Emerald Group Publishing.

[43] Laniel, M., Uysal, J. \& Emond, J. P. (2011). Radio frequency interactions with air cargo container materials for real-time cold chain monitoring. Applied Engineering in Agriculture, 27(4), 647-652.

[44] Lu, H.A. \& Chen, C.Y. (2011). A time-space network model for unit load device stock planning in international airline services. Journal of Air Transport Management, 17(2), 94100. https://doi.org/10.1016/j.jairtraman.2010.09.004

[45] Michaga, M.F.R., Michailos, S., Hughes, K.J., Ingham, D., \& Pourkashanian, M. (2021). 10 - Techno-economic and life cycle assessment review of sustainable aviation fuel produced via biomass gasification. Sustainable Biofuels, 269-303. https://doi.org/10.1016/B978-0-12-820297$5.00012-8$

[46] Mu, H., \& Tang, J. (2019). The composite control method for the GDI engine idle speed control. International Journal of Circuits, Systems, and Signal Processing, 13, 97-104.

[47] Neale, B. (2018). What is qualitative longitudinal research? London: Bloomsbury Publishing. 
[48] O'Leary, Z. (2004). The essential guide to doing research. London: SAGE Publications.

[49] Ong, M. (2017). Scoot and Tigerair merger: What can we expect? Retrieved from https://www.asiaone.com/travel/scoot-and-tigerair-mergerwhat-can-we-expect.

[50] Ortega Alba, S., \& Manana, M. (2017). Characterization and analysis of energy demand patterns in airports. Energies, 10(1), 119. https://doi.org/10.3390/en10010119

[51] Otley, T. (2019). Airbus A350: What you need to know. Retrieved from https://www.businesstraveller.com/features/a350-what-youneed-to-know/.

[52] Rahim, A. R., \& Baksh, M. S. (2003). Case study method for new product development in engineer-to-order organisations, Work Study, 52(1), 25-36. https://doi.org/10.1108/00438020310458705

[53] Ramaswamy, K. (2002). Singapore International Airlines: Strategy with a smile. Thunderbird International Business Review, 44(4), 533-555. https://doi.org/10.1002/tie.10027

[54] Rice, C., Ragbir, N.K., Rice, S., \& Barcia, G. (2020). Willingness to pay for sustainable aviation depends on ticket price, greenhouse gas reductions and gender. Technology in Society, 60 101224 https://doi.org/10.1016/j.techsoc.2019.101224

[55] Roberts, A. (2018). Airside resource planning. In P.J. Bruce, Y. Gao \& J.M.C. King (Eds.), Airline operations: A practical guide (pp. 152-161). Abingdon: Routledge

[56] Scott, J. 2004. Documents, types of. In: M. Lewis-Beck, A.E. Bryman. \& T. Futing Liao (Eds.), The SAGE encyclopedia of social science research methods (pp. 281284). Thousand Oaks: SAGE Publications.

[57] Scott, J. (2014). A dictionary of sociology (4th ed.). Oxford: Oxford University Press.

[58] Scott, J. \& Marshall G. (2009). A dictionary of sociology (3rd ed.). Oxford; Oxford University Press.

[59] Simons, G.M. (2014). The Airbus A380: A history. Barnsley: Pen \& Sword Aviation.

[60] Singapore Airlines. (2013). Sustainability report 2012/13. Retrieved from https://www.singaporeair.com/saar5/pdf/InvestorRelations/Annual-Report/sustainabilityreport1213.pdf.

[61] Singapore Airlines. (2014). Sustainability report 2013/14. Retrieved from https://www.singaporeair.com/saar5/pdf/InvestorRelations/Annual-Report/sustainabilityreport1314.pdf.

[62] Singapore Airlines. (2015). Sustainability report 2014/15. Retrieved from https://www.singaporeair.com/saar5/pdf/InvestorRelations/Annual-Report/sustainabilityreport1415.pdf.

[63] Singapore Airlines. (2016). Sustainability report 2015/16. Retrieved from
https://www.singaporeair.com/saar5/pdf/Investor-

Relations/Annual-Report/sustainabilityreport1516.pdf.

[64] Singapore Airlines. (2017). Sustainability report 2016/17. Retrieved from https://www.singaporeair.com/saar5/pdf/InvestorRelations/Annual-Report/sustainabilityreport1617.pdf.

[65] Singapore Airlines. (2018). Sustainability report 2017/18. Retrieved from https://www.singaporeair.com/saar5/pdf/InvestorRelations/Annual-Report/sustainabilityreport1718.pdf.

[66] Singapore Airlines. (2019). Sustainability report 2018/19. Retrieved from https://www.singaporeair.com/saar5/pdf/InvestorRelations/Annual-Report/sustainabilityreport1819.pdf.

[67] Singapore Airlines. (2020). Sustainability report 2019/20. Retrieved from https://www.singaporeair.com/saar5/pdf/InvestorRelations/Annual-Report/sustainabilityreport1920.pdf.

[68] Singapore Airlines. (2021). Sustainability report 2020/21. Retrieved from https://www.singaporeair.com/saar5/pdf/InvestorRelations/Annual-Report/sustainabilityreport2021.pdf.

[69] Singh, J., Sharma-Kumar, S., \& Srivastava, R. (2018). Managing fuel efficiency in the aviation sector: challenges, accomplishments and opportunities. FIIB Business Review, 7(4), 244-251. https://doi.org/10.1177\%2F2319714518814073

[70] Sloan, C. (2019). Flashback: Flying the inaugural 380 with Singapore Airlines (2007). Retrieved from https://airwaysmag.com/special-flights/onboard-a380inaugural-flight-2007/.

[71] Sreenath, S., Sudhakar, K., \& Yusop, A.F. (2021). Energyexergy-economic-environmental-energo-exergoenviroecono (7E) analysis of solar photovoltaic power plant: A case study of 7 airport sites in India. Sustainable Energy Technologies and Assessments, 47, 101352. https://doi.org/10.1016/j.seta.2021.101352

[72] Staples, M.D., Malina, R., Suresh, P., Hileman, J.I. \& Barrett, S.R.H. (2014). Aviation $\mathrm{CO}_{2}$ emissions reductions from the use of alternative jet fuels. Energy Policy, 114, 342-354. https://doi.org/10.1016/j.enpol.2017.12.007

[73] Tsai, W.H., Chang, W.C., Lin, S.J., Chen, H.C., \& Chu, P.Y. (2014). A green approach to the weight reduction of aircraft cabins. Journal of Air Transport Management, 40, 65-77. https://doi.org/10.1016/j.jairtraman.2014.06.004

[74] Turner, P.A., \& Lim, S.H. (2015). Hedging jet fuel price risk: The case of U.S. passenger airlines. Journal of Air Transport Management, 44-45, 54-64. https://doi.org/10.1016/j.jairtraman.2015.02.007

[75] United States Environmental Protection Agency. (2021). Local renewable energy benefits and resources. Retrieved from https://www.epa.gov/statelocalenergy/local-renewableenergy-benefits-and-resources. 
[76] Vasigh, B., \& Rowe, Z.C. (2020). Foundations of airline finance: Methodology and practice (3rd ed.). Abingdon: Routledge.

[77] Vasigh, B., Taleghani, R., \& Jenkins, D. (2012). Aircraft finance: Strategies for managing capital costs in a turbulent industry. Fort Lauderdale.

[78] Wensveen, J.G. (2016). Air transportation: A management perspective (8th ed.). Abingdon: Routledge.

[79] Yerel Kandemir S., \& Yayli, M. Ö. (2016). Investigation of renewable energy sources for airports. In T. Hikmet, M. Baris Ozerdem, C.O. Colpan, O. Altuntas, E. Acikkalp (Eds.), Sustainable aviation: Energy and environmental issues (pp. 11-16). Cham, Switzerland: Springer International Publishing.

[80] Yildirim, U., \& Abanteriba, S. (2012). Manufacture, qualification and approval of new aviation turbine fuels and additives. Procedia Engineering, 49, 310-315. https://doi.org/10.1016/j.proeng.2012.10.142

[81] Yin, R.K. (2018). Case study research and applications (6th ed.). Thousand Oaks: SAGE Publications.

[82] Zou, B., Kwan, I., Hansen, M., Rutherford, D., \& Kafle, N. (2016). Airline fuel efficiency: Assessment methodologies and applications in the U.S. domestic airline industry. In J.D. Bitzan., J. Peoples \& W.W. Wilson (Eds.), Airline efficiency (pp. 317-352). Bingley: Emerald Group Publishing. 